\title{
Incidence and susceptibility of aerobic Gram-negative bacilli from 20 Canadian intensive care units: 1989-1993
}

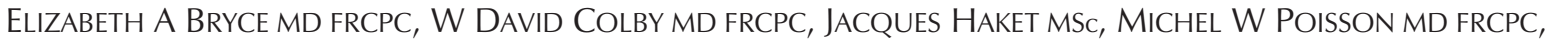 \\ JOHN A SMITH MD FRCPC
}

EA BRYCE, WD COLBY, J HAKET, MW POISSON, JA SMITH. Incidence and susceptibility of aerobic Gram-negative bacilli from 20 Canadian intensive care units: 1989-1993. Can J Infect Dis 1996;7(1):34-40.

OBJECTIVE: To assess the prevalence of antibiotic resistance in Canadian intensive care units. DESIGN: The antimicrobial profiles of $1939 \mathrm{Gram}$-negative bacilli isolated in 20 Canadian intensive care units were analyzed using a custom designed MicroScan panel.

SETTING: The majority of the hospitals were tertiary care institutions, but some community hospitals were included. PATIENTS: Adult intensive care unit patients were the sources of isolates.

MAIN RESULTS: Pseudomonas aeruginosa was the most frequently isolated microorganism overall, with Escherichia coli the most common initial isolate. Comparison of initial and repeat isolates showed that $P$ aeruginosa readily acquired resistance to all antibiotic classes except the aminoglycosides. Enterobacter aerogenes developed resistance to ciprofloxacin and Enterobacter cloacae demonstrated resistance to all beta-lactam antibiotics except for imipenem on repeat isolation. Other Enterobacteriaceae remained susceptible. Historical comparison with data derived four years previously from 15 of the centres showed increased resistance of P aeruginosa and Acinetobacter species to ciprofloxacin while other susceptibility patterns remained stable.

CONCLUSIONS: The prevalence of Gram-negative resistance in Canadian hospitals is less than that reported in surveys done in some other countries, and was relatively stable over four years.

Key Words: Antibiotics, Intensive care units, Resistance

Incidence et sensibilité des bacilles gram-négatifs aérobies provenant de 20 unités de soins intensifs canadiens - 1989-1993

OBJECTIF : Évaluer la prévalence de la résistance aux antibiotiques dans les unités de soins intensifs au Canada. MODÈLE : Profil antimicrobien de 1939 bacilles gram-négatifs isolés dans 20 unités de soins intensifs au Canada qui ont été analysés à l'aide d'une plaque MicroScan faite sur commande.

voir page suivante

Division of Medical Microbiology, Department of Pathology, Vancouver Hospital, Vancouver, British Columbia; Division of Microbiology, University Hospital and University of Western Ontario, London, Ontario; Merck Frosst Canada Inc, Kirkland, Quebec; and Department of Microbiology and Infectious Disease, Hôtel-Dieu, Montreal, Quebec

Correspondence: Dr W David Colby, Division of Microbiology, University Hospital, 339 Windermere Road, London, Ontario N6A 5A5.

Telephone 519-663-3396, fax 519-663-3743, e-mail wcolby@julian.uwo.ca

Received for publication February 8, 1995. Accepted May 24, 1995 
CONTEXTE : La majorité des hôpitaux étaient des établissements de soins tertiaires, mais certains hôpitaux communautaires ont été inclus.

PATIENTS : Les sources des isolats ont été des patients d'unités de soins intensifs pour adultes.

PRINCIPAUX RÉSULTATS : Pseudomonas aeruginosa a été le microorganisme le plus souvent isolé de façon globale, Escherichia coli étant l'isolat initia lle plus commun. La comparaison des isolats de départ et des isolats lors d'infections répétées a montré que $\mathrm{P}$. aeruginosa pouvait acquérir facilement une résistance à toutes les classes d'antibiotiques à l'exception des aminosides. Enterobacter aerogenes a développé une résistance à la ciprofloxacines et Enterobacter cloacae a démontré une résistance à toutes les bêta-lactamines à l'exception de l'imipénem lors de prélèvements répétés. D'autres Enterobacteriaceae sont demeurés sensibles. La comparaison historique avec des données dérivées quatre ans auparavant de 15 des centres a démontré une résistance accrue de P. aeruginosa et des Acinetobacter à la ciprofloxacine, alors que les autres modes de sensibilité sont demeurés stables.

CONCLUSION : La prévalence de la résistance des organismes gram-négatifs dans les hôpitaux canadiens est moindre que ce que l'on avait rapporté dans les enquétes épidémiologiques effectuées dans les autres pays et ont été relativement stables pendant quatre ans.

$\mathrm{N}$ osocomial infections are a significant cause of mortality and morbidity in patients hospitalized in intensive care units (ICUs), with infection rates disproportionately higher than in general wards (1). Gram-negative pathogens predominate, with Pseudomonas aeruginosa and Enterobacter species accounting for $21 \%$ of isolates in a survey of adult and pediatric ICUs in the United States (2). The choice of appropriate antimicrobial regimens in such critically ill patients is crucial. Therapeutic decisions are influenced by antibiotic resistance patterns, which change in response to the pressure of antimicrobial use, changes in patient population, prevalence of microorganisms and the emergence of new resistance mechanisms. Hospital-wide surveys of resistance can serve as guides in antibiotic selection, but the epidemiology of ICU resistance may not be discerned by that approach.

This study examined the antimicrobial profiles of 1939 Gram-negative bacilli isolated from patients hospitalized in 20 Canadian ICUs over a six-month period in 1993. Resistance in Gram-negative bacilli was studied because of their predominance as ICU pathogens and because of the selective pressure exerted upon them by the new beta-lactam antibiotics. The purpose of the survey was to determine the prevalence of isolates and their patterns of resistance and to compare these with the patterns previously noted in the 15 centres that participated in a similar study in 1989.

\section{PATIENTS AND METHODS}

Microorganisms: A total of 1939 isolates of aerobic Gramnegative bacilli were obtained from blood, urine, lower respiratory tract, wound, peritoneal cavity, abscess and indwelling line specimens of ICU patients in 20 Canadian teaching hospitals. Each participating hospital laboratory collected approximately 100 consecutive isolates, which were identified by standard methods. Once identified, isolates were stored frozen until susceptibility tests were performed. Repeat isolates of the same species from the same patient site were excluded unless they were collected at least $48 \mathrm{~h}$ apart. No attempts were made to differentiate strains of the same species. Standard quality control strains of Escherichia coli and P aeruginosa from the American Type Culture Collection were used according to the guidelines of the National Committee for Clinical Laboratory Standards (NCCLS) (3).
Patients: There were no patient exclusion criteria and 852 adult patients contributed one or more isolates to the study. Patient demographic data were not recorded. Patients were prescribed treatment by their attending physicians without regard to the study.

Antimicrobial susceptibility tests: Broth microdilution minimum inhibitory concentration (MIC) tests were performed using custom MicroScan CAN91 panels (Baxter Diagnostics Inc, California) with 16 antimicrobials at four doubling dilutions above and below the susceptibility breakpoints. Dilutions were performed using brain-heart infusion broth according to the manufacturer's recommendations. The antibiotics tested were amikacin, ampicillin, ampicillin/sulbactam, cefoperazone, cefotaxime, ceftazidime, ciprofloxacin, gentamicin, imipenem, piperacillin, ticarcillin, ticarcillin/clavulanate and tobramycin. The plates were read at 18 to $24 \mathrm{~h}$ and interpreted according to the criteria described in the NCCLS document M100-S4:(M7A2) (3).

Study design and analysis: Each of the 20 participating laboratories received the study protocol, broth microdilution plates and reagents, and standardized data recording forms. The results were entered into a computer database at Merck Frosst Canada Inc, Kirkland, Quebec. The prevalence of bacterial species and overall percentage of resistance to the antibiotics tested were separately analyzed for initial and repeat isolates. Historical comparison was undertaken in 15 of the 20 centres that had participated in a similar study of 33 Canadian ICUs done in 1989-90 as a Merck Frosst local surveillance project (4). This previous study used MicroScan MIC Plus Type 2 panels (Baxter Diagnostics Inc) and identical patient selection and microorganism sampling criteria. A two-tailed Fisher's exact test was used to calculate P values with 0.05 as the threshold of significance.

\section{RESULTS}

1993 data analysis: Twenty centres contributed 1939 isolates from 852 patients in 1993. Initial isolates comprised $66.7 \%$ of the total (1293) and $33.3 \%$ (646) were repeat specimens. The majority were from respiratory specimens (1113) followed by urine (249), wounds (221), blood and other sterile sites (226), catheter tip cultures (117) and miscellaneous other sites (13). The frequency and percentage susceptibility of species with 
TABLE 1

Frequency and percentage of susceptibility of common isolates (20 centres, 1993, initial and repeat isolates)

\begin{tabular}{|c|c|c|c|c|c|c|c|c|c|c|c|c|c|c|c|}
\hline \multirow[b]{2}{*}{ Species } & \multirow[b]{2}{*}{$\begin{array}{l}\text { Number } \\
\text { of isolates }\end{array}$} & \multicolumn{12}{|c|}{ Antibiotic } & \multirow[b]{2}{*}{$\begin{array}{c}\text { AMK } \\
16 \\
\end{array}$} & \multirow[b]{2}{*}{$\begin{array}{c}\mathrm{CP} \\
1 \\
\end{array}$} \\
\hline & & $\begin{array}{c}\text { IPM } \\
4^{*}\end{array}$ & $\begin{array}{c}\text { CAZ } \\
8\end{array}$ & $\begin{array}{c}\text { CFT } \\
8\end{array}$ & $\begin{array}{c}\text { CAX } \\
8\end{array}$ & $\begin{array}{l}\text { CFP } \\
16\end{array}$ & $\begin{array}{c}\text { TIM } \\
16\end{array}$ & $\begin{array}{c}T \\
16\end{array}$ & $\begin{array}{l}\text { PIP } \\
16\end{array}$ & $\begin{array}{c}\text { AMP } \\
8\end{array}$ & $\begin{array}{c}\text { AS } \\
8\end{array}$ & $\begin{array}{c}\mathrm{GM} \\
4\end{array}$ & $\begin{array}{c}\text { TOB } \\
4\end{array}$ & & \\
\hline $\begin{array}{c}\text { Pseudomonas } \\
\text { aeruginosa }\end{array}$ & 433 & 81 & 85 & 18 & 23 & 80 & 83 & 88 & 92 & 0 & 0 & 73 & 96 & 92 & 83 \\
\hline $\begin{array}{l}\text { Escherichia } \\
\text { coli }\end{array}$ & 372 & 100 & 98 & 98 & 98 & 90 & 88 & 73 & 75 & 70 & 73 & 95 & 96 & 99 & 98 \\
\hline $\begin{array}{c}\text { Enterobacter } \\
\text { cloacae }\end{array}$ & 222 & 99 & 61 & 61 & 59 & 63 & 53 & 53 & 60 & 9 & 29 & 96 & 96 & 99 & 95 \\
\hline $\begin{array}{l}\text { Klebsiella } \\
\text { pneumoniae }\end{array}$ & 196 & 98 & 96 & 95 & 94 & 94 & 93 & 5 & 69 & 3 & 87 & 95 & 95 & 98 & 96 \\
\hline $\begin{array}{l}\text { Stenotrophomonas } \\
\text { maltophilia }^{+}\end{array}$ & 122 & 2 & 59 & 10 & 4 & 40 & 56 & 28 & 33 & 4 & 8 & 9 & 5 & 13 & 9 \\
\hline $\begin{array}{l}\text { Serratia } \\
\text { marcescens }\end{array}$ & 115 & 97 & 100 & 96 & 96 & 93 & 90 & 81 & 93 & 6 & 11 & 98 & 80 & 98 & 91 \\
\hline $\begin{array}{l}\text { Klebsiella } \\
\text { oxytoca }\end{array}$ & 74 & 98 & 97 & 98 & 94 & 93 & 94 & 6 & 66 & 1 & 86 & 100 & 100 & 100 & 100 \\
\hline $\begin{array}{c}\text { Enterobacter } \\
\text { aerogenes }\end{array}$ & 72 & 100 & 65 & 76 & 69 & 63 & 52 & 50 & 61 & 13 & 37 & 98 & 98 & 98 & 91 \\
\hline $\begin{array}{l}\text { Acinetobacter } \\
\text { species }^{\ddagger}\end{array}$ & 65 & 100 & 89 & 60 & 69 & 18 & 92 & 90 & 66 & 26 & 93 & 66 & 69 & 76 & 67 \\
\hline $\begin{array}{l}\text { Proteus } \\
\text { mirabilis }\end{array}$ & 65 & 96 & 100 & 100 & 100 & 96 & 100 & 95 & 96 & 89 & 90 & 96 & 98 & 98 & 96 \\
\hline $\begin{array}{c}\text { Morganella } \\
\text { morganii }\end{array}$ & 40 & 85 & 87 & 87 & 95 & 87 & 77 & 75 & 82 & 5 & 27 & 95 & 100 & 90 & 100 \\
\hline $\begin{array}{l}\text { Citrobacter } \\
\text { freundii }\end{array}$ & 35 & 100 & 57 & 60 & 57 & 57 & 54 & 48 & 54 & 17 & 45 & 85 & 88 & 88 & 85 \\
\hline $\begin{array}{l}\text { Acinetobacter } \\
\text { anitratus }\end{array}$ & 23 & 100 & 82 & 47 & 52 & 8 & 82 & 82 & 52 & 8 & 95 & 78 & 86 & 91 & 82 \\
\hline $\begin{array}{l}\text { Proteus } \\
\text { vulgaris }\end{array}$ & 16 & 93 & 100 & 68 & 43 & 62 & 100 & 43 & 62 & 0 & 56 & 100 & 100 & 100 & 100 \\
\hline
\end{tabular}

*Breakpoint ( $\mu \mathrm{g} / \mathrm{mL}) ;{ }^{\dagger}$ Formerly Xanthomonas maltophilia; ${ }^{\ddagger}$ Excluding A anitratus. AMK Amikacin; AMP Ampicillin; AS Ampicillin/sulbactam; CAX Ceftriazone; CAZ Ceftazidime; CFP Cefoperzone; CFT Cefotaxime; CP Ciprofloxacin; GM Getamicin; IPM Imipenem; P Piperacillin; T Ticarcillin; TIM Timentin; TOB Tobramycin

greater than 10 isolates is presented in Table 1 . Fifty species were represented in the survey, with 14 species comprising more than $95 \%$ of all isolates.

$\mathrm{P}$ aeruginosa was the most frequently isolated organism overall, followed by E coli, which was the most common initial isolate.

E coli, Klebsiella species and Proteus species were susceptible to beta-lactam drugs, aminoglycosides and ciprofloxacin. $\mathrm{P}$ aeruginosa and Xanthomonas maltophilia (since renamed Stenotrophomonas maltophilia) accounted for the greatest proportion of resistance overall, except to ceftazidime and ticarcillin/clavulanate for which the inducible Enterobacteriaceae (ie, Enterobacter species, Citrobacter freundii, Morganella morganii) and Acinetobacter species dominated.

Comparison of the susceptibility patterns of initial and repeat isolates of the 11 most common species (Table 2) showed that $\mathrm{P}$ aeruginosa readily acquired resistance to all the agents except to the aminoglycosides and ticarcillin/clavulanate. Enterobacter aerogenes developed resistance to ciprofloxacin and Enterobacter cloacae developed resistance to the cephalosporins, ticaracillin/clavulanate and to ciprofloxacin but re- mained susceptible to imipenem and the aminoglycosides. The noninducible Enterobacteriaceae (ie, Klebsiella species and $\mathrm{E}$ coli) remained susceptible on repeat isolation except for an increase in resistance to tobramycin in Klebsiella pneumoniae.

Historical data analysis: Fifteen of the 20 centres in the 1993 study also participated in a similar survey in 1989-90 (4). Susceptibilities to nine of the antibiotics were determined in both of studies, and the NCCLS breakpoints remained the same. The frequency of distribution of the microorganisms (as a percentage of all initial isolates) was stable over time, except for Acinetobacter species, which was relatively less frequent in 1993. Table 3 demonstrates changes that occurred since 1989-90 in susceptibility to antibiotics common to both studies. The only increase in resistance noted was to ciprofloxacin in P aeruginosa and Acinetobacter species.

\section{DISCUSSION}

The participating ICUs in this susceptibility survey represented a broad cross-section of Canadian hospitals, from tertiary care teaching centres to community hospitals, ranging 


\section{TABLE 2}

Percentage susceptibility of selected antibiotics for the 11 most common microorganisms (initial versus repeat isolates)

\begin{tabular}{|c|c|c|c|c|c|c|c|c|c|c|c|c|c|c|c|c|c|c|c|c|}
\hline \multirow[b]{3}{*}{ Species } & \multirow{2}{*}{\multicolumn{2}{|c|}{$\begin{array}{l}\text { Number of } \\
\text { isolates }\end{array}$}} & \multicolumn{18}{|c|}{ Antibiotic } \\
\hline & & & \multicolumn{2}{|c|}{ Imipenem } & \multicolumn{2}{|c|}{ Ceftazidime } & \multicolumn{2}{|c|}{ Cefotaxime } & \multicolumn{2}{|c|}{ Ceftriaxone } & \multicolumn{2}{|c|}{ Timentin } & \multicolumn{2}{|c|}{ Gentamicin } & \multicolumn{2}{|c|}{ Tobramycin } & \multicolumn{2}{|c|}{ Amikacin } & \multicolumn{2}{|c|}{ Ciprofloxacin } \\
\hline & Initial & Repeat & Initial & Repeat & Initial & Repeat & Initial & Repeat & Initial & Repeat & Initial & Repeat & Initial & Repeat & Initial & Repeat & Initial & Repeat & Initial & Repeat \\
\hline $\begin{array}{l}\text { Escherichia } \\
\text { coli }\end{array}$ & 275 & 97 & 100 & 100 & 98 & 98 & 97 & 98 & 97 & 98 & 89 & 85 & 95 & 93 & 96 & 96 & 99 & 98 & 98 & 100 \\
\hline $\begin{array}{c}\text { Pseudomonas } \\
\text { aeruginosa }\end{array}$ & 230 & 203 & 87 & $73^{*}$ & 89 & $80^{*}$ & 23 & $12^{*}$ & 26 & 21 & 86 & 79 & 74 & 71 & 96 & 96 & 93 & 91 & 87 & $78^{*}$ \\
\hline $\begin{array}{c}\text { Enterobacter } \\
\text { cloacae }\end{array}$ & 143 & 79 & 100 & 98 & 67 & $49^{*}$ & 68 & $48 *$ & 66 & $46^{*}$ & 59 & $43^{*}$ & 97 & 96 & 97 & 96 & 99 & 98 & 97 & 93 \\
\hline $\begin{array}{l}\text { Klebsiella } \\
\text { pneumoniae }\end{array}$ & 141 & 55 & 97 & 100 & 97 & 92 & 97 & 92 & 95 & 92 & 94 & 90 & 96 & 94 & 97 & $90^{*}$ & 99 & 98 & 95 & 98 \\
\hline $\begin{array}{l}\text { Serratia } \\
\text { marcescens }\end{array}$ & 70 & 45 & 97 & 97 & 100 & 100 & 97 & 95 & 97 & 95 & 92 & 86 & 97 & 100 & 75 & 88 & 98 & 97 & 91 & 91 \\
\hline $\begin{array}{r}\text { Klebsiella } \\
\text { oxytoca }\end{array}$ & 56 & 18 & 98 & 100 & 96 & 100 & 98 & 100 & 94 & 94 & 92 & 100 & 100 & 100 & 100 & 100 & 100 & 100 & 100 & 100 \\
\hline $\begin{array}{c}\text { Enterobacter } \\
\text { aerogenes }\end{array}$ & 48 & 24 & 100 & 100 & 64 & 66 & 77 & 75 & 68 & 70 & 54 & 50 & 100 & 95 & 100 & 95 & 100 & 95 & 97 & $79^{*}$ \\
\hline $\begin{array}{l}\text { Proteus } \\
\text { mirabilis }\end{array}$ & 48 & 17 & 95 & 100 & 100 & 100 & 100 & 100 & 100 & 100 & 100 & 100 & 95 & 100 & 97 & 100 & 97 & 100 & 95 & 100 \\
\hline $\begin{array}{l}\text { Acinetobacter } \\
\text { species }\end{array}$ & 44 & 21 & 100 & 100 & 90 & 85 & 59 & 61 & 75 & 57 & 90 & 95 & 70 & 57 & 75 & 57 & 75 & 80 & 72 & 57 \\
\hline $\begin{array}{l}\text { Citrobacter } \\
\text { freundii }\end{array}$ & 26 & 9 & 100 & 100 & 61 & 44 & 65 & 44 & 61 & 44 & 57 & 44 & 84 & 88 & 88 & 88 & 92 & 77 & 92 & 66 \\
\hline $\begin{array}{c}\text { Morganella } \\
\text { morganii }\end{array}$ & 27 & 13 & 81 & 92 & 92 & 76 & 92 & 76 & 100 & 84 & 85 & 61 & 100 & 84 & 100 & 100 & 96 & 76 & 100 & 100 \\
\hline
\end{tabular}


TABLE 3

Historical comparison in percentage of susceptibility of initial isolates (same 15 centres, 1989 versus 1993)

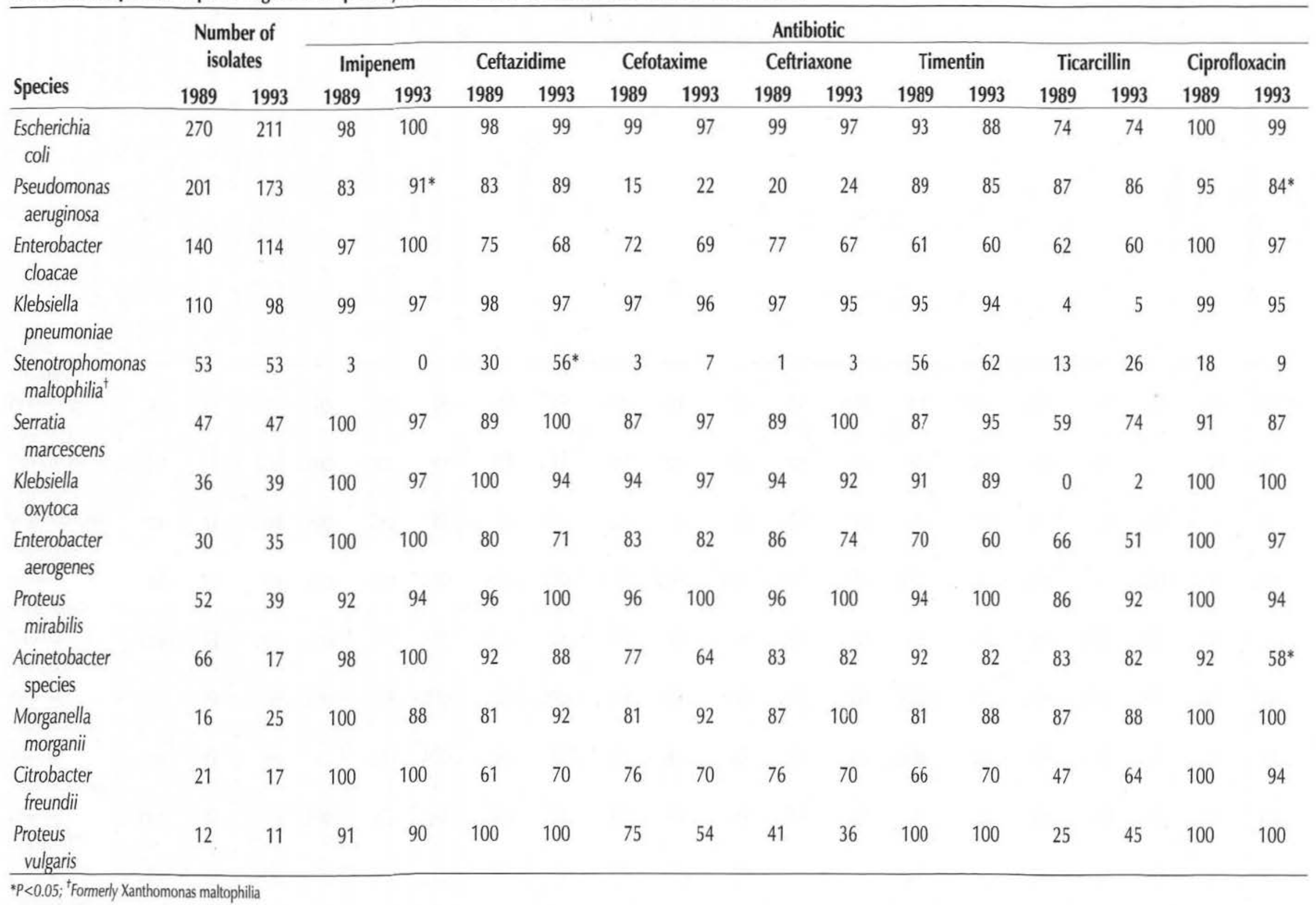


across a wide geographic area. By restricting our study to isolates from ICUs, we focused on microorganisms with the greatest potential for resistance. The proportion of isolates derived from the anatomical areas sampled in our study was similar to the frequency of ICU infections by site described in other recent surveys (5-7). The clinical significance of isolates was not assessed and no attempts were made to determine whether isolates were part of nosocomial outbreaks.

The broth microdilution method was selected as an easily reproducible standardized method for all centres. It also afforded comparison with the data collected in 1989-90. This method has recently been found to have less sensitivity than agar dilution or the $\mathrm{E}$ test in detecting plasmid-mediated, extended spectrum beta-lactamases (8). The data may therefore somewhat underrepresent the true prevalence of beta-lactam resistance in E coli and Klebsiella species.

The pooled resistance data for the 20 hospitals showed that E coli, and Klebsiella and Proteus species were susceptible to the beta-lactam drugs, aminoglycosides and ciprofloxacin, even the repeat isolates (Table 2). This suggests that the prevalence of the extended spectrum, plasmid-mediated betalactamases remained low in Canada in 1993.

The inducible Enterobacteriaceae (Enterobacter species, $\mathrm{C}$ freundii and Morganella morganii) and Acinetobacter species demonstrated considerable resistance to beta-lactam antibiotics, including third-generation cephalosporins, even on initial isolation. Resistance to imipenem was not seen in these organisms. This pattern of resistance to third-generation cephalosporins and susceptibility to imipenem is consistent with class I beta-lactamase activity (9).

Comparison of initial with repeat isolates revealed striking decreases in susceptibility to cephalosporins and ticarcillin/ clavulanate in $\mathrm{E}$ cloacae isolates. In addition to betalactamase-mediated resistance, increased resistance to ciprofloxacin was noted in $\mathrm{E}$ aerogenes. Fluoroquinolone resistance is largely due to mutant DNA gyrases, but the emergence of such resistance in common with beta-lactam resistance is more likely due to increased drug extrusion across the cytoplasmic membrane (10). P aeruginosa rapidly developed resistance to beta-lactam antibiotics (including imipenem) and ciprofloxacin but not to aminoglycosides. Reduced susceptibility to imipenem can occur in $\mathrm{P}$ aeruginosa as a combination effect of chromosomal beta-lactamase and loss of the $\mathrm{D} 2$ porin (11). Avoiding extended courses of broad spectrum betalactam agents when possible and reculturing and retesting antimicrobial sensitivities during prolonged courses of therapy may be advisable.

Except for ceftazidime and ticarcillin/clavulanate resistance in initial isolates of inducible Enterobacteriaceae, $\mathrm{P}$ aeruginosa and $\mathrm{S}$ maltophilia accounted for the largest proportion of resistance overall. S maltophilia displayed the greatest resistance and is known to express a zinc-based beta-lactamase that endows it with broad spectrum resistance to beta-lactam drugs, including imipenem (12).

Opportunities to study changes in isolate frequencies and antibiotic resistance patterns over time, particularly with the same methods and study sites, are few. We were able to com- pare data for 15 centres common to both study periods. Initial isolates were chosen to eliminate distortions due to excessive numbers of repeat isolates from 'jackpot' patients, resulting in a more accurate depiction of changes in susceptibility over time.

The proportion of Acinetobacter species isolated was significantly lower in the 1993 study than in the 1989-90 study. The isolation frequencies of the other microorganisms were remarkably similar, in contrast to other surveys in which Enterobacter species have been noted to be increasing $(13,14)$. An increase in resistance to ciprofloxacin among $\mathrm{P}$ aeruginosa and Acinetobacter species was the only significant change in resistance noted and may reflect increased use of the drug in the community as well as in the hospital setting. The absence of increased beta-lactam resistance compared with recent reports from the United States $(13,14)$ may be due in part to policies restricting certain antibiotics in the majority of Canadian hospitals and to the six-month to one-year lag in Canadian drug licensing compared with the United States.

The potential for rapid emergence of resistance, particularly in $\mathrm{P}$ aeruginosa and the inducible Enterobacteriaceae, is ever-present. This report provides indirect evidence for the efficacy of rational antibiotic policies and continuing education of physicians in practices that minimize the emergence of antibiotic resistance.

ACKNOWLEDGEMENTS: The authors acknowledge the following investigators for their collaboration in this study: Drs Michael Achong, Colina Jones and David Groves, St Joseph's Hospital, Hamilton, Ontario; Drs Michele Alfa and Godfrey Harding, St Boniface General Hospital, Winnipeg, Manitoba; Drs John Bohnen and Krystyna Ostrowska, the Wellesley Hospital, Toronto, Ontario; Dr Alison Clarke, St Paul's Hospital, Vancouver, British Columbia; Dr Suzanne Claveau, Hôtel-Dieu de Québec, Québec, Québec; Dr Mona Crowley, St John Regional Hospital, St John, New Brunswick; Dr Andre Dascal, Jewish General Hospital, Montreal, Quebec; Dr David Haldane, Victoria General Hospital, Halifax, Nova Scotia; Dr Peter Jessamine, Ottawa Civic Hospital, Ottawa, Ontario; Dr Pamela Kibsey, Grey Nuns Hospital, Edmonton, Alberta; Dr Michel Laverdière, Hôpital Maisonneuve-Rosemont, Montréal, Québec; Dr Thomas Louie, Calgary General Hospital, Calgary, Alberta; Drs John Marshall and Anne Phillips, the Toronto Hospital, Toronto, Ontario; Mr WT Martin, Royal University Hospital, Saskatoon, Saskatchewan; Drs Warren Mayo and Barbara Robinson, Lions Gate Hospital, North Vancouver, British Columbia; Dr Hugh Robson, Royal Victoria Hospital, Montreal, Quebec; Dr Andrew Simor, Sunnybrook Health Sciences Centre, North York, Ontario. This work was supported by Merck Frosst Canada Inc.

\section{REFERENCES}

1. Pittet D, Herwaldt LA, Massanari RM. The intensive care unit. In: Bennett JV, Brachman PS, eds. Hospital Infections. Boston: Little, Brown and Co, 1992:405-39.

2. Jarvis WR, Edwards JR, Culver DH, et al. Nosocomial infection rates in adult and paediatric intensive care units in the United States. Am J Med 1991;(Suppl 3B):185-91.

3. National Committee for Clinical Laboratory Standards. Methods for Dilution Antimicrobial Susceptibility Tests for Bacteria that Grow Aerobically. Approved Standard M7-A2 (M100-S4). Villanova: National Committee for Clinical Laboratory Standards, 1993.

4. Incidence of multiresistance in serial Gram-negative isolates from intensive care units. Kirkland: Merck-Frosst Canada Inc, 1990. 
5. Shah PM, Asanger R, Kahan FM. Incidence of multi-resistance in Gram negative aerobes from intensive care units of 10 German hospitals. Scand J Infect Dis 1991;78(Suppl):22-34.

6. Verbist L. Incidence of multi-resistance in Gram negative bacterial isolates from intensive care units in Belgium: a surveillance study. Scand J Infect Dis 1991;78(Suppl):48-53.

7. Snydman DR. Clinical implications of multi-drug resistance in the intensive care unit. Scand J Infect Dis 1991;78(Suppl):54-63.

8. Katsanis GP, Spargo J, Ferraro MJ, et al. Detection of Klebsiella pneumoniae and Escherichia coli strains producing

extended-spectrum $\beta$-lactamases. J Clin Microbiol 1994;32:691-6.

9. Richmond MH, Sykes RB. The $\beta$-lactamases of Gram-negative bacteria and their possible physiological role. Adv Microb Physiol 1973;9:31-88.
10. Nikaido H. Outer membrane barrier as a mechanism of antimicrobial resistance. Antimicrob Agents Chemother 1989;33:1831-6.

11. Livermore DM. Interplay of impermeability and chromosomal $\beta$-lactamase activity in imipenem-resistant Pseudomonas aeruginosa. Antimicrob Agents Chemother 1992;36:2046-8

12. Bush K. Classification of $\beta$-lactamases: groups $2 \mathrm{c}, 2 \mathrm{~d}, 2 \mathrm{e}, 3$ and 4. Antimicrob Agents Chemother 1989;33:271-6.

13. Schaberg DR, Culver DH, Gaynes RP. Major hands in the microbial etiology of nosocomial infection. Am J Med 1991;(Suppl 3B):72-5

14. Sanders CC, Sanders WG Jr. $\beta$-lactam resistance in Gram negative bacteria: global trends and clinical impact. Clin Infect Dis 1992;15:824-39. 


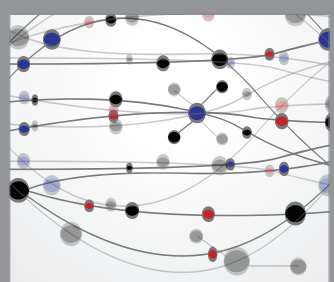

The Scientific World Journal
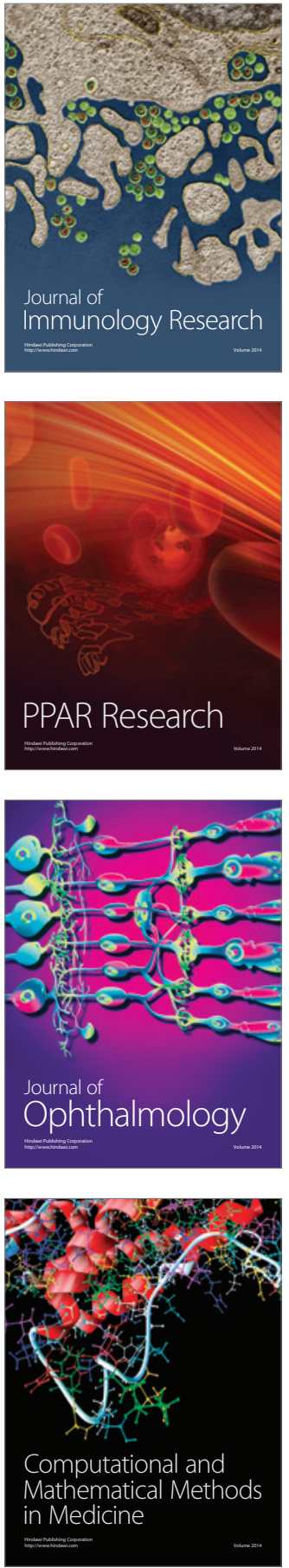

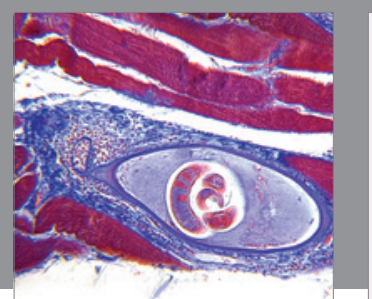

Gastroenterology Research and Practice

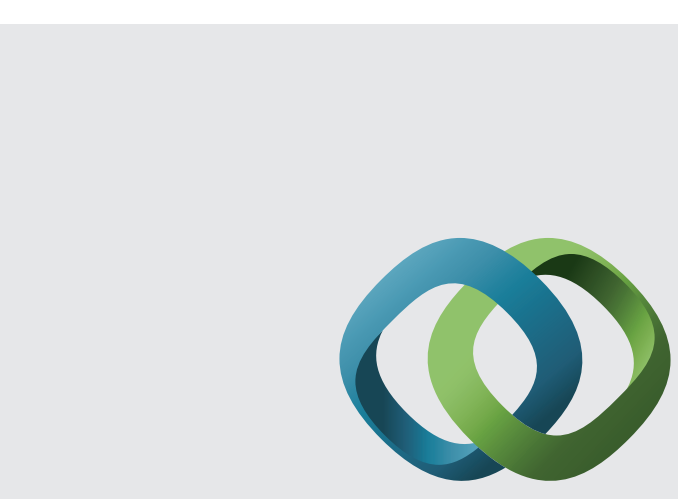

\section{Hindawi}

Submit your manuscripts at

http://www.hindawi.com
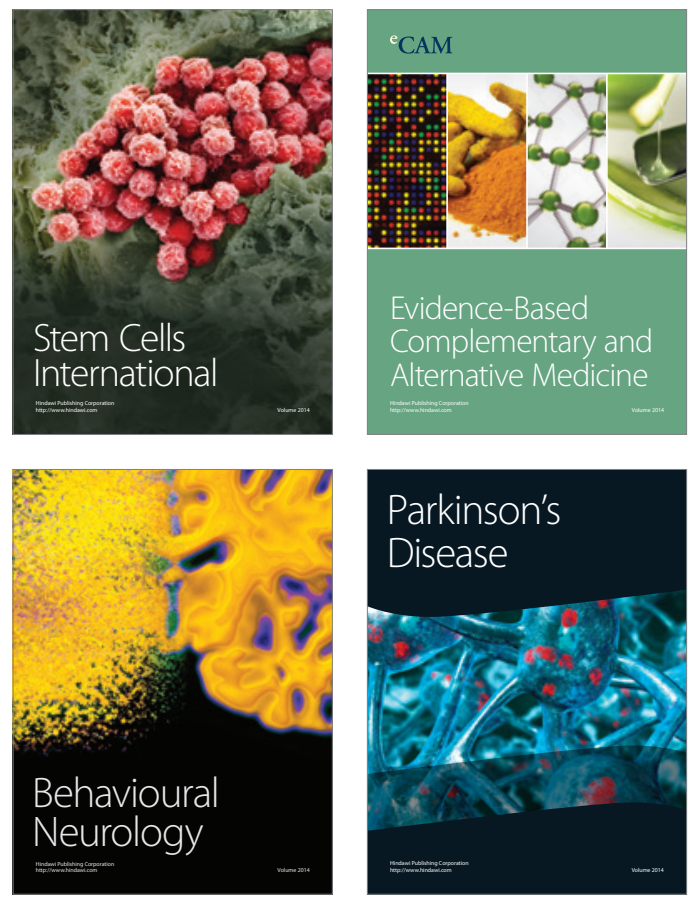
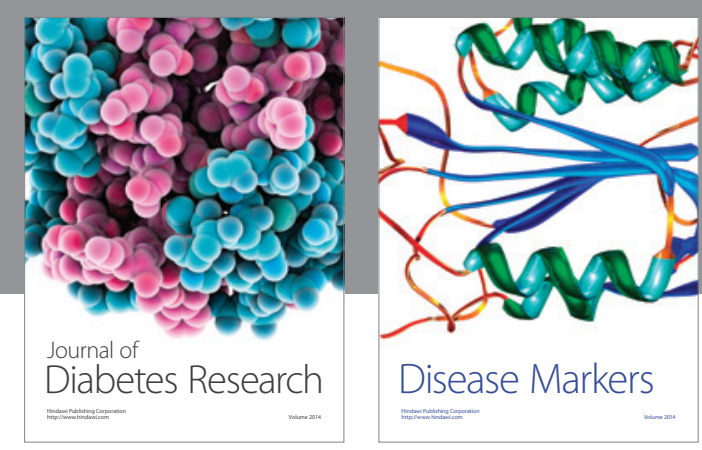

Disease Markers
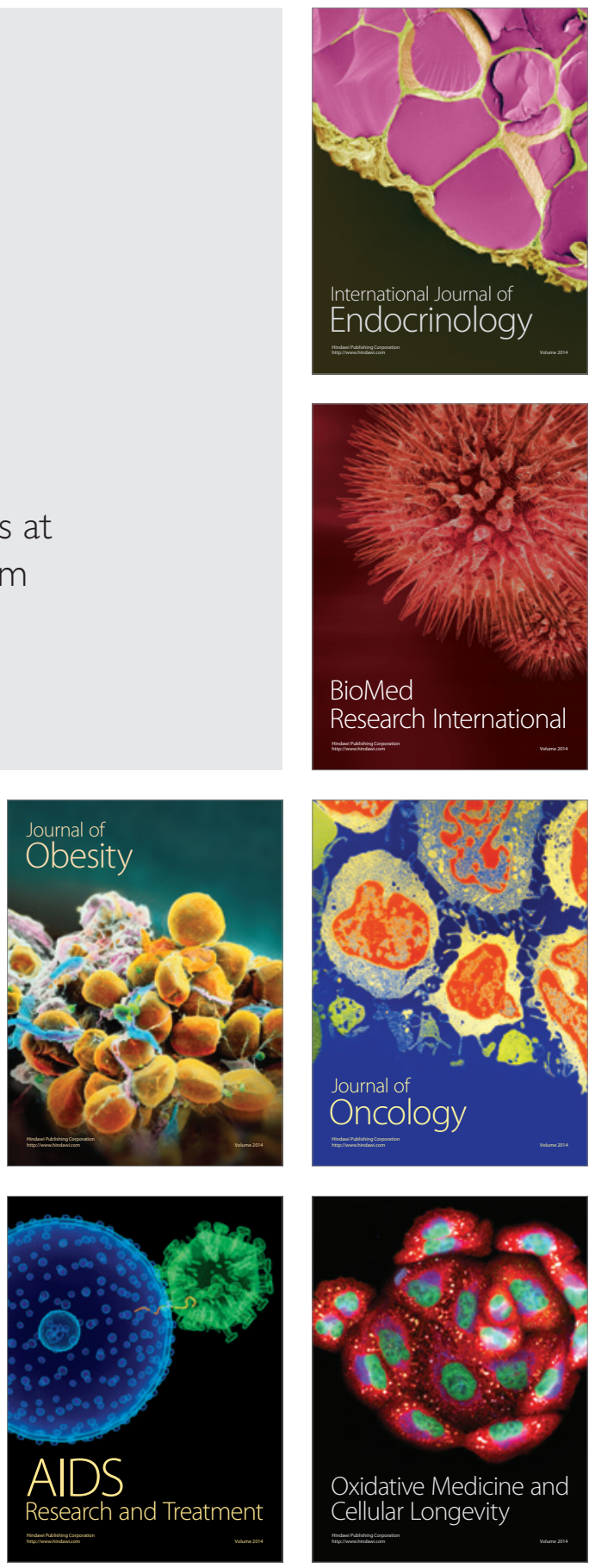